\title{
PERSONAL PROTECTION OF PEOPLE DURING A PANDEMIC
}

\begin{abstract}
The article focuses on the general principles regarding personal protection of people during a pandemic. The author indicates the difference between the concepts of an epidemic and a pandemic, characterizes civil protection, and specifies classification and possibilities of incorporating personal means of protection against biological infection. The text also highlights measures that contribute to protection of health and life of civilians as well as personal means of protection in the armed forces.

The publication is based on the analysis of available literature on the subject. In the research process, the author used his many years of experience in the Armed Forces of the Republic of Poland (the chemical troops), including data gathered from simulation of conduct in CBRN (Chemical, Biological, Radiological and Nuclear) contaminated environment.
\end{abstract}

\section{Key words}

infectious diseases, pandemics, civil protection, personal protection measures 
"Ebola virus is invisible, except through an electron microscope or by way of its pathogenic effects.

(...) It is apolitical. It seems to kill like the 10th plague of Egypt in Exodus - the one inflicted by an angel of death".

(Quammen, 2014, p. 1)

\section{Introduction}

Infectious diseases, which often lead to millions of deaths, have been a serious threat to human health and life since time immemorial. The greatest outbreaks recorded in the last millennium include: the Black Death (1348-1351, killed approx. 25 million, that is, a third of the population of the Old Continent), smallpox (1520-1979 - approx. 56 million deaths), the Great Plague of London (1665-1666 - approx. 100 thousand deaths), cholera outbreaks (1899-1923 - approx. 1 million), the Spanish flu (1918-1920 - approx. 40-50 million victims; according to other sources - 100 million), SARS-CoV (2002-2003 - approx. 800 thousand), A/H1N1 influenza (2009-2010 - approx. 200 thousand), Ebola virus (2014-2016 - approx. 11.3 thousand). Infectious diseases have repeatedly decimated humanity.

Not that long ago, the author of the article wrote in one of his monographs that "infectious diseases also bring a lot of suffering these days - at least 17 million people die every year due to these invisible killers (that is, 50 thousand people daily)" (Michailiuk, 2015a, p. 14). At that time, the author also highlighted possible detrimental effects of increasing this number due to having pathogen control so as to cause a pandemic on purpose. Unfortunately, even if not as a result of a deliberate interference in the virus, we face now the threat of a pandemic that claims thousands of lives every day.

The most recent pandemic is caused by the new SARS-CoV-2 coronavirus causing the disease called COVID-19. First noted in late 2019 in China, the disease spread quickly. As of 11 March 2020, 118,318 infections and 4292 fatalities were recorded globally (WHO, 2020c)), while on 11 February 2020, the respective numbers were only 43,103 and 1018 (WHO, 2020a). By that time it had reached Europe, including Poland, where the first case was confirmed on 4 March 2020, whereas on 11 March 2020 there were 22 cases (WHO, 2020b). The numbers illustrate why it is crucial to immediately react to the epidemic threat in the country. 
The aim of the research is to present the issues related to civil protection in the face of a pandemic and to indicate methods of civil protection in the event of its occurrence. The above implies the need to define the concepts of epidemics, pandemics and civil protection. The author focuses his research on civil protection in the aspect of personal and collective protective measures undertaken during a pandemic. The purpose of this article is to discuss selected personal and collective means of protection, which aim at reducing the risk of adverse effects stemming from the contact with a dangerous virus. The article also speaks about the importance of supporting humanity in stopping the COVID-10 pandemic, which is drastically spreading across the world.

In this article, the author used the method of desk research. What was extremely helpful in the writing were the available references and the unpublished information about the research area. Another contributing factor were the author's many years of experience in the specialized military subunits of the Polish Armed Forces (the chemical troops), including active participation in simulation of conduct in CBRN (Chemical, Biological, Radiological and Nuclear) contaminated environment.

\section{Epidemic vs pandemic - differentiation of concepts and historical background}

Prior to pointing specific differences between an epidemic and a pandemic, what should be defined first is the notion of an "infectious disease" which is an integral part of the above concepts. Infectious disease is understood as "a disease that was caused by a biological pathogen" (Ustawa $\mathrm{z}$ dnia 5 grudnia 2008 , art. 2, point 3) which "has the capacity to cause disease symptoms, [or by] cellular microorganisms or their products, external and internal human parasites or products they make, cell-free particles that are capable of replication or transfer of genetic material, including genetically modified cell cultures or products they make" (Ustawa $\mathrm{z}$ dnia 5 grudnia 2008, art. 2, point 2). Strains of most known pathogens are officially stored for scientific purposes in Centers for Disease Control and Prevention (CDC) in Atlanta, US as well as in a secret Russian government laboratory near Novosibirsk.

The vast majority of all cases diagnosed as infectious diseases are caused by viruses. For example, in the period of 1975-2000, infectious diseases of viral etiology amounted to $49,973,000$, that is $93.8 \%$ of the total $53,370,000$ of severe infectious diseases (Kańtoch, n.d.). The existence of viruses was first speculated upon in the 1840s by Jakob Henle, but undeniable evidence of their existence 
was demonstrated by Meyer, who in 1880 conducted the first experiment aimed at demonstrating virus infection. However, it was only in 1935 that Wendell Stanley isolated the virus in its pure form, and four years later, it was first seen thanks to the use of an electron microscope (Moore, 2009, pp. 21-23). Viruses are organisms deprived of the ability to act independently because they require living cells, in which they can reproduce. Owing to the fact that they are a peculiar "packet that contains only code", they are virtually invisible and highly dependent on cells of their host, which keep infecting others. They cause diseases that generally do not respond to antibiotics, but to a limited extent, they can be defeated by antiviral compounds (Michailiuk, 2015a, p. 14). "Contemporary taxonomy includes several thousand viruses that are pathogenic to humans, animals, and plants. Humans are the natural host for many viruses, while for others natural hosts are animals; however, people are also a link in the virus circulation" (Kańtoch, n.d.).

In the context of this article, it is essential to provide a brief description of a specific type of pathogens known as coronaviruses. They are RNA viruses from the family of Coronaviridae, whose genome is ribonucleic acid; they have one of the largest genomes among the RNA viruses that infect humans. Their covering consists of "numerous thick rod-like protrusions, which under the electron microscope look as if they formed a crown or a halo resembling a solar corona (the name of coronavirus comes from the Latin word which stands for a wreath or crown)" (Krawczyk, 2020, p. 28). The first reports concerning human coronaviruses come from the 1960s, when it became possible to isolate and describe two pathogens - HcoV-229E and HCoV-OC43. For many years, coronaviruses have remained at the margins of virology research due to the fact that the two mentioned species cause only a mild cold passing within days without any intervention. It was only at the beginning of the 21st century that an epidemic caused by a previously unknown, highly contagious SARS coronavirus occurred in the world. In 2012, 10 years after the first SARS-CoV epidemic, cases were noted of a new acute respiratory disease, often fatal, caused by MERS coronavirus (Pyrć, 2015, p. 48). 8 years later, the world experienced another outbreak of a coronavirus-caused disease, which, however, could not be contained to a single region. The new SARS-CoV-2 coronavirus is a fat-protected (lipid) membrane RNA virus. The most common symptoms of the disease are fever, coughing, shortness of breath, and breathing problems. The disease may be accompanied by muscle aches and fatigue. 
Table 1. Epidemics and pandemics over the years - selected examples

\begin{tabular}{|c|c|c|c|c|}
\hline \multirow{2}{*}{ Type of disease } & \multirow{2}{*}{ Type/host } & \multirow{2}{*}{ Time } & \multicolumn{2}{|c|}{ Number of cases } \\
\hline & & & infected people & fatalities \\
\hline Black Death & $\begin{array}{c}\text { Yersinia Pestis } \\
\text { bacteria; rat, flea }\end{array}$ & $1348-1351$ & unknown & 75-200 million \\
\hline Spanish flu & H1N1 virus; pig & 1918-1920 & approx. 500 million & 21-100 million \\
\hline SARS & $\begin{array}{l}\text { coronavirus; } \\
\text { bat, civet, } \\
\text { raccoon dog }\end{array}$ & $2002-2003$ & 8422 & 916 \\
\hline $\begin{array}{l}\text { Avian influenza } \\
\text { "bird flu" }\end{array}$ & H5N1; poultry & $2003-2006$ & 861 & 455 \\
\hline $\begin{array}{l}\text { Mexican flu, } \\
\text { "swine flu" }\end{array}$ & $\begin{array}{l}\text { A/H1N1; } \\
\text { swine }\end{array}$ & $\begin{array}{l}11 \text { June 2009- } \\
10 \text { Aug } 2010\end{array}$ & 250-500 million & $150-580$ thousand \\
\hline MERS & $\begin{array}{l}\text { coronavirus; } \\
\text { bat, camel }\end{array}$ & Sep 2012- & $\begin{array}{c}2494 \\
\text { (as of } 30 \text { Nov 2019) }\end{array}$ & $\begin{array}{c}858 \\
\text { (as of } 30 \text { Nov 2019) }\end{array}$ \\
\hline Ebola & $\begin{array}{l}\text { Ebola virus; } \\
\text { wild animal }\end{array}$ & 2013-2016 & $\begin{array}{c}28646 \\
\text { (as of } 30 \text { March 2016) }\end{array}$ & $\begin{array}{c}11323 \\
\text { (as of } 30 \text { March 2016) }\end{array}$ \\
\hline COVID-19 & $\begin{array}{l}\text { coronavirus; } \\
\text { unknown } \\
\text { (presumably } \\
\text { pangolin, bat) }\end{array}$ & 30 Nov $2019-\ldots$ & $\begin{array}{c}118319 \\
\text { (as of 11 March 2020) }\end{array}$ & $\begin{array}{c}4292 \\
\text { (as of 11 March 2020) }\end{array}$ \\
\hline
\end{tabular}

Source: own study based on available sources.

In the light of the above, the term "epidemic" is used to describe the occurrence of "infections or cases of an infectious disease in a significantly higher number than in the previous period or the occurrence of infections or infectious diseases not yet present in a given area [and at a given time]" (Ustawa $\mathrm{z}$ dnia 5 grudnia 2008, art. 2, point 9). When the epidemic begins to cover large areas around the world, spreads to many countries, and one of its features is the high incidence in the population, then this phenomenon can be defined as pandemic (Carlos, 2020; Bradshaw \& Stahl, 2020). It is worth differentiating the concept of a pandemic and an endemic disease - the latter relates to the situation when 
a specific infectious disease persists in a given area for many years at a similar level, e.g. the West African outbreak of Ebola hemorrhagic fever in 2014.

On 11 March 2020, Director General of the World Health Organization (WHO) Tedros Adhanom Ghebreyesus announced the COVID-19 pandemic, thus recognizing that the epidemic of the new coronavirus that started in November 2019 in Wuhan (China) has turned into the global pandemic of SARSCoV-2 coronavirus (WHO Director-General, 2020).

\section{Civil protection}

The term "protection" is understood as "providing safety against injury, damage, loss, and other negative situations" (Flemming et al., 1997, p. 6). This statement indicates that the concept of protection is related to all people. In the literature, the term "protection" is used in the context of e.g. monuments, forest, landscape, personal data. There is also environmental protection, nature protection, fire protection, personal protection, protection of property, health, work, etc. Three areas of civil protection can be pointed out based on the information above, as presented in the drawing below.

Figure 1. Civil protection - areas

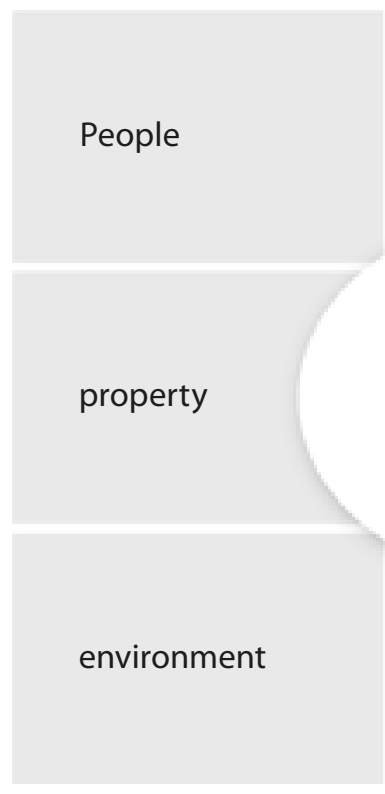

Civil protection

Source: own study. 
Protection is a sphere of security which mainly focuses on ensuring human existence, regardless of what causes the danger (Michailiuk, 2015b). In case of a threat to military or non-military activities, it is of great significance to undertake proper actions, which aim at saving lives and health, evacuating the population, providing basic survival conditions for the survivors, and securing property.

Therefore, the implementation of tasks in the field of civil protection should cover three main areas:

- monitoring, informing, and warning about threats

- saving lives, health, property, and the environment

- providing emergency assistance based on ensuring basic conditions for survival.

The analysis of the definition of "protection", as indicated in legal documents and encyclopedic sources, allows us to highlight specific features of this concept, including:

- intentional and organized action/inaction

- rational operation carried out by specialized entities

- issuing relevant legal regulations

- counteracting, preventing, and eliminating threats

- consequences and prevention

- restoring the state that existed before the threat (Flemming et al., 1997, p. 7).

Thus protection is associated with the following tasks: monitoring, counteracting, preparing, responding, and removing the effects of adverse events. It encompasses four phases:

1. prevention - minimizing potential losses

2. vigilance

3. responding to threats

4. reconstruction - restoring the state from before (Michailiuk, 2014, pp. 245-246).

The above phases clearly show similarities to the phases that are distinguished in crisis management. These activities are very alike, but "it should be stated that while crisis management is a legally identifiable system, the civil protection system is still not legally sanctioned" (Sobolewski et al., 2016, p. 97).

Detailed steps taken at personal stages are presented in the figure below. 
Figure 2. Civil protection: stages of taking action

\begin{tabular}{|c|c|c|c|}
\hline & \multicolumn{2}{|c|}{ Civil protection - stages of taking action } & \\
\hline $\begin{array}{c}\text { prevention, } \\
\text { such as actions aimed } \\
\text { at minimizing losses, } \\
\text { including: legislative work, } \\
\text { planning, inventorying, } \\
\text { establishing } \\
\text { organizational structures, } \\
\text { construction of buildings, } \\
\text { and security systems } \\
\text { (hiding places, shelters, } \\
\text { levees, border control, } \\
\text { transport control, etc.) }\end{array}$ & $\begin{array}{l}\text { readiness, } \\
\text { including: } \\
\text { conducting research, } \\
\text { improving } \\
\text { rescue services } \\
\text { and expanding } \\
\text { their equipment, } \\
\text { public education, } \\
\text { training, } \\
\text { and exercises, } \\
\text { developing } \\
\text { operating proced }\end{array}$ & $\begin{array}{l}\text { responding to } \\
\text { threats, } \\
\text { including: targeting } \\
\text { centers and coordination } \\
\text { centers, searching } \\
\text { and providing } \\
\text { assistance to injured } \\
\text { parties, eliminating } \\
\text { dangerous outbreaks, } \\
\text { mobilizing rescue } \\
\text { services and volunteers, } \\
\text { informing authorities, } \\
\text { mass media, } \\
\text { and society }\end{array}$ & $\begin{array}{l}\text { reconstruction, } \\
\text { which stands } \\
\text { for restoring the normal state } \\
\text { including: loss estimation, } \\
\text { information concerning } \\
\text { rights and duties, } \\
\text { efficient administration, } \\
\text { activation of reconstruction } \\
\text { of damage, analyzing needs } \\
\text { and fulfillment of obligations } \\
\text { providing social assistance, } \\
\text { specifying applications }\end{array}$ \\
\hline
\end{tabular}

Source: own study.

Civil protection occurs in two forms:

- collective - carried out by state institutions (includes activities such as evacuating people, creating places of refuge, detecting threats, and alerting the society about them)

- personal - based on the knowledge and skills of a single citizen regarding behavior in the face of a specific danger (knowledge of first aid, evacuation procedures, alarm signals, storage of water and food) (Michailiuk, 2017).

Actions targeted at ensuring civil protection are conducted irrespective of conditions and the situation of the state (Regulation of 21 September 2004). There are three stages of implementing this type of tasks (Michailiuk, 2017, p. 246):

1. vigilance and emergency response - daily routine activities to save people, property, and the environment as well as elimination of adverse effects; including actions aimed at preventing and counteracting threats

2. protection of people during a war, in accordance with the principles of international law. 
Figure 3. Civil protection - personal and collective protection measures

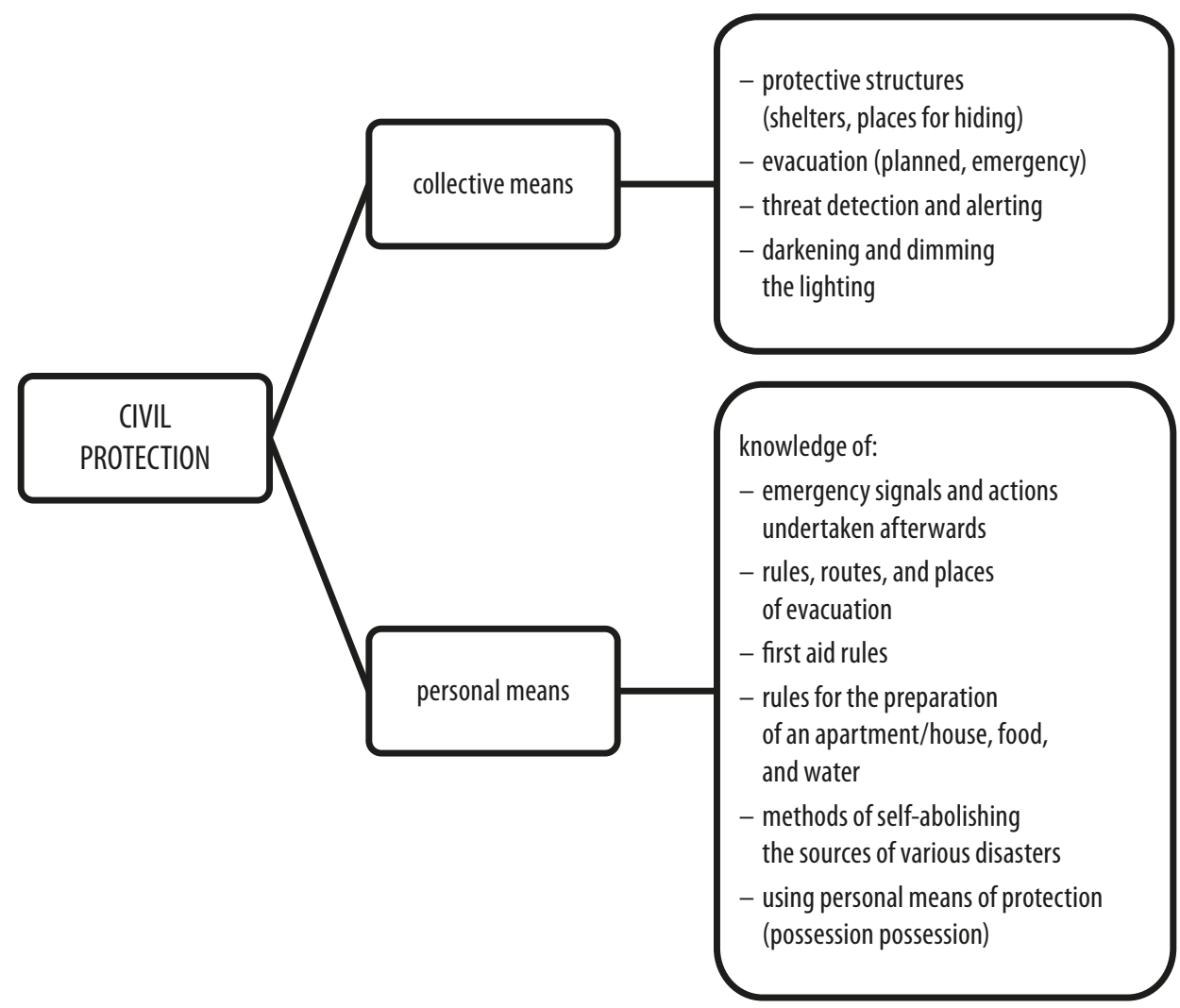

Source: own study.

\section{2a. Preparation of the civilians}

Pandemic is an unusual condition that puts to the test not only the state and the services, but also the whole society. When people are faced with high contagiousness of a disease, protection against infection becomes the highest priority. Mass incidence is a new, mostly unknown and distant phenomenon that people need to become familiar with. It is worthwhile to learn how to take adequate steps both on a collective and personal scale.

The most obvious advice is to follow disinfection rules and adhere to the proper use of personal measures to protect oneself against infection.

There are no physical barriers that can protect society against pathogenic microorganisms. On the positive side, the vast majority of biological agents do not act on the damaged skin layer and do not penetrate this way into the living 
organism. Therefore, for most of us, isolation (or at least minimizing interpersonal contacts) and protection guaranteed by properly used masks and gloves is sufficient. Wearing protective clothing is a necessity for medical staff (cf. Sholapurkar, 2020).

The most common personal protection product is a disposable surgical mask (see Photo 1).

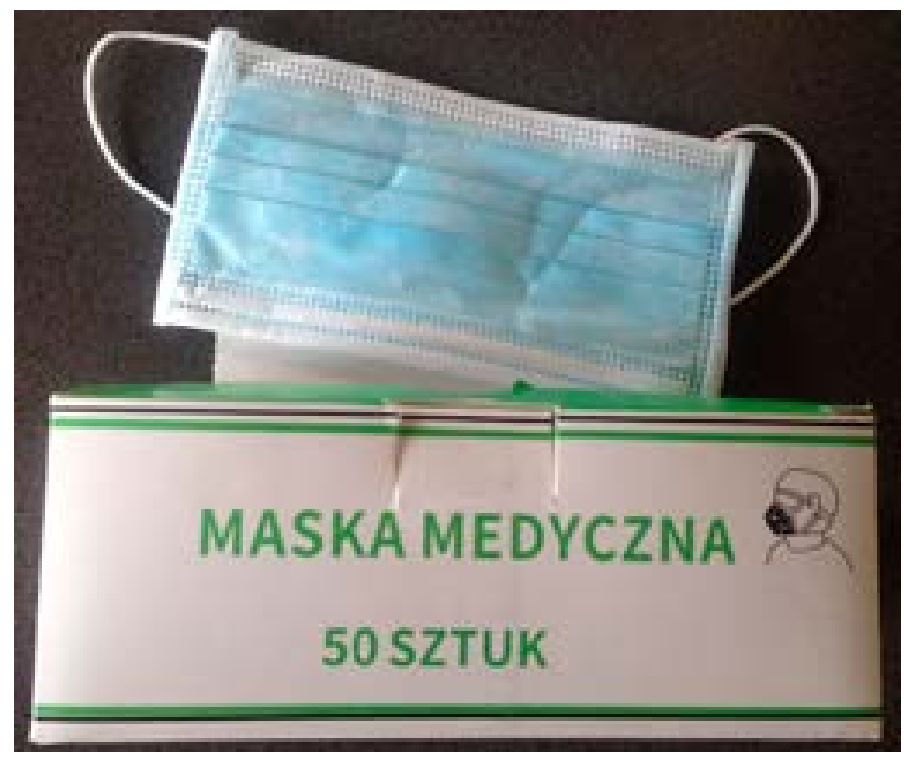

Photo 1. Disposable mask

Source: author's private archive.

European Standard 14683: 2019 stipulates strict standards for surgical masks, indicating relevant requirements for effectiveness of bacterial filtration, pressure differential to measure breathing resistance, and resistance to leakage. It is noteworthy that the EU is aware of the seriousness of the situation, the importance and complexity of real and potential emergency situations. It can be observed in EU Directives as well as in a number of standardization documents regarding the need to provide personal protection at workplaces and during operations carried out in extreme conditions.

The purpose of masks is not only to filter the air, but also to ensure isolation of the face (mouth and nose) from external factors. Masks provide protection against particles with a diameter above $1 \mu \mathrm{m}$ (SARS-CoV-2 virions reach a size of 0.08-0.14 $\mu \mathrm{m}$ ). According to EN 14683: 2019, there are several categories of disposable surgical masks (Surgical masks, 2019): 
- Type I and Type IR provide optimal protection thanks to bacterial filtration and proper adhesion to one's face, simultaneously preserving breathing comfort (with filtration efficiency $\geq 95 \%$;

- Type II and Type IIR are additionally resistant to seepage, which guarantees safety against exposure to blood and other potentially infectious liquids (with filtration efficiency $\geq 98 \%$ ).

However, the vision of a long-lasting epidemic encourages limiting expenses. That is why reusable protective masks are frequently used (see Photo 2). Manufacturers emphasize that their products maintain protective properties even after several washings. Such masks should be washed with soap or sanitizer.

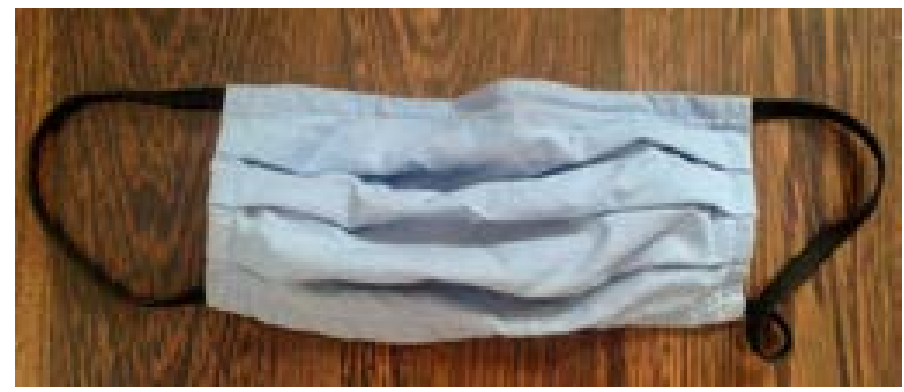

Photo 2. Reusable mask

Source: author's private archive.

Filter masks are another type of masks used as means of personal protection. Owing to their filtering efficiency, the following protection classes (Surgical masks, 2019) can be distinguished:

- Class 1 (FFP1) - with 80\% filtration efficiency (used to protect against solid and liquid particles of low toxicity);

- Class 2 (FFP2) - with 94\% filtration efficiency (used to protect against solid and liquid particles of low and medium toxicity);

- Class 3 (FFP3) - with a 97\% filtration efficiency (used to protect against solid and liquid particles of high toxicity).

When at risk of exposure to harmful pathogens, it is equally important to wear protective gloves (see Photo 3). They are usually made of plastic (e.g. nitrile rubber, latex or polyethylene). Such gloves provide protection against infection by accidental contact with a virus. They also protect from direct contact and the transfer of pathogens to one's body (e.g. by touching one's eye with a finger). 
Similarly to masks, observing the principles of proper use of protective gloves (putting on, using, removing, disposal) is immensely significant.

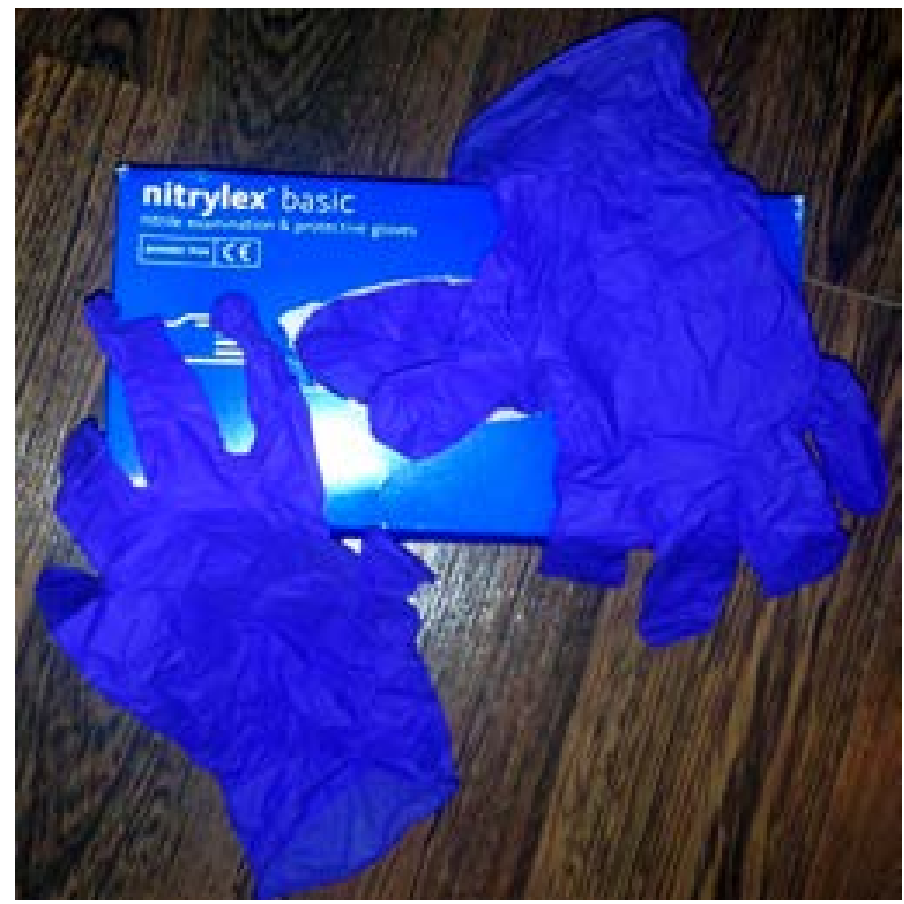

Photo 3. Protective gloves

Source: author's private archive.

Sanitizers are another measure useful in personal protection. Disinfection is a "process that destroys vegetative forms of microorganisms (bacterial spores and slow viruses remain)" (Dezynfekcja..., p. 1).

Disinfection can be carried out using the following methods:

- thermal

- thermal and chemical

- chemical.

Chemical disinfection means using "disinfection solutions of chemical preparations with different properties. The active substances are chlorine-based compounds, peroxygen compounds, quaternary ammonium compounds, alcohols, aldehydes, and phenol derivatives. The choice of the appropriate preparation depends on the current or expected infection, the type of disinfected material, and the toxicity of the agent" (Dezynfekcja..., p. 2). 
According to the recommendations of the Polish Ministry of Health, everyone should use available virucidal substances and preparations, including disinfectant liquids and hand sanitizers, as well as alcohol wipes (see Photo 4).

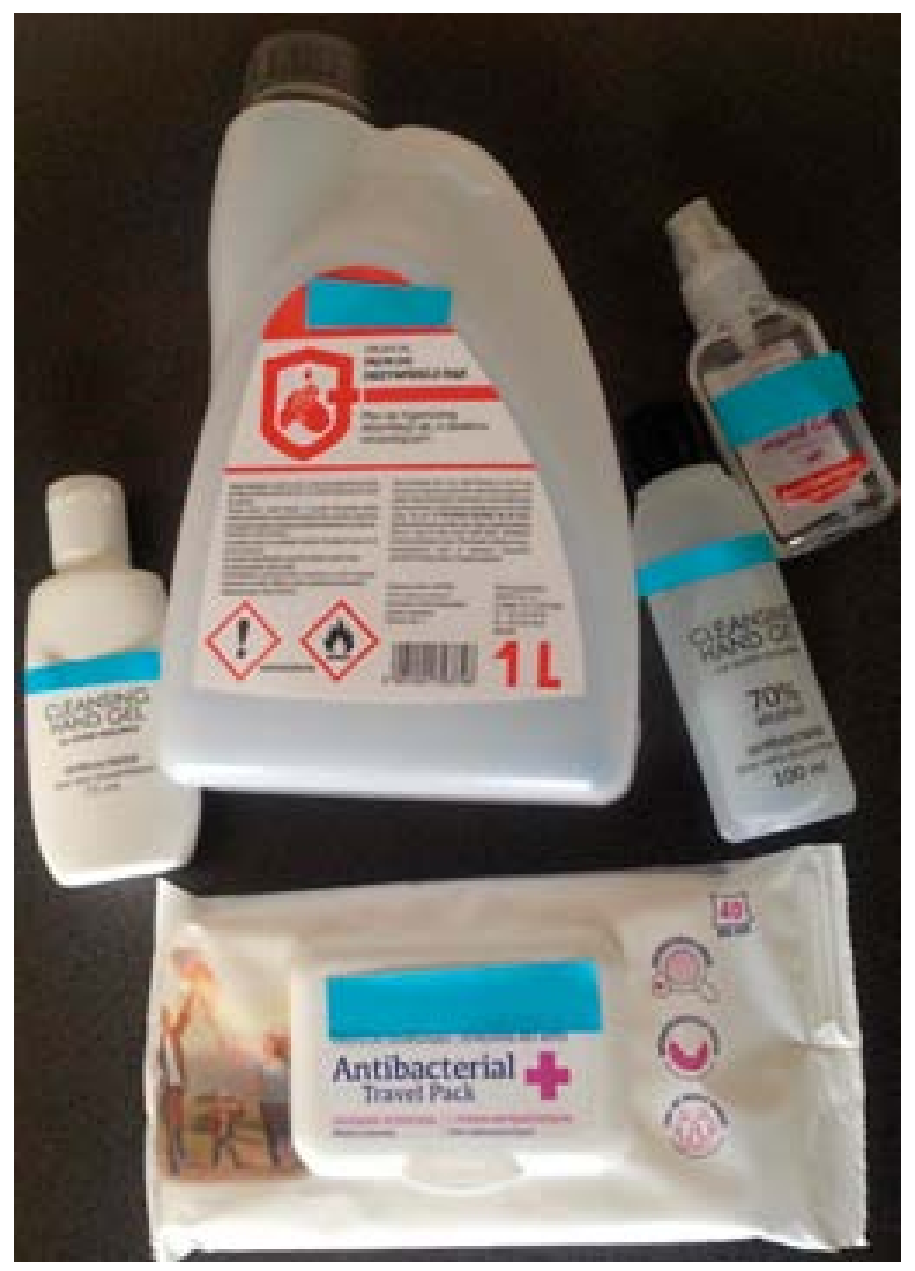

Photo 4. Means of disinfection

Source: author's private archive.

Employers also have special obligations during a pandemic - it is their responsibility to ensure adequate protection measures at workplaces. If the employers' intention is to ensure continuity and efficiency of the business, they must provide specific control of employees in terms of health condition as well as ensure that the employees have adequate protective measures (protective masks, 
hand sanitizers). Minimizing the number of employees present at the premises or reorganizing the work mode must be conducted in such a way as to avoid crowds and gathering large numbers of people in one room/building, which is dangerous during an epidemic.

The situation looks significantly different in medical services for people who are "at the front line with an invisible enemy" (cf. Lemke et al., 2020). Managers of health care entities and other people responsible for health services are required by law to take measures to prevent the spread of infections and infectious diseases (Ustawa $\mathrm{z}$ dnia 5 grudnia 2008, art. 11 (1)), including "the use of personal and collective protection measures to prevent the transmission of biological pathogens to other people" (Ustawa z dnia 5 grudnia 2008, art. 2 (4)). The principle of priority to introduce collective protection measures over personal protection measures should be emphasized. The former group includes all activities related to:

- administrative organization

- legal issues

- technology.

They are aimed at creating comprehensive protection against the biological agents (solutions regarding preventive, supportive, and control measures) (Michailiuk, 2017, pp. 85-112; Żółtowski, 1969, pp. 255-256) and include:

- identifying disease outbreaks as quickly as possible (appropriate tests)

- laboratory diagnostics of materials

- limiting the spread of the virus (preventing contact of infected people with healthy population, and preventing the development of infection during its incubation period

- disinfection, disinfestation, and mass sanitation

- monitoring the state of the environments in which the largest number of infections occur

- ensuring circulation of information between management bodies in the event of emergency

- continually informing relevant entities; keeping the public updated about the threat

- intensifying research on the vaccine/drugs that may help.

First and foremost, the group of personal protective equipment includes protective masks, respirators protecting the respiratory tract, protective gloves, protective suits, disinfectants and virucidal fluids. In accordance with the guidelines of the European Center for Disease Prevention and Control (ECDC), 
the following items should be included as part of the minimum package securing a single healthcare professional (Coronavirus: European Standard):

- to protect one's body - a waterproof apron with long sleeves

- for eye protection - goggles or safety glasses, a visor

- for respiratory protection - an FFP2 or FFP3 class half-mask (alternatively, surgical masks)

- for hand protection - gloves made of plastic (e.g. nitrile rubber, latex, polyethylene etc., which must be worn over the apron while it is put on.

The standard procedure encourages thorough hand washing and disinfection. Similarly, proper hygiene and disinfection of the hands must be observed during removal of personal protective equipment. Potentially contaminated clothing items should be disposed of in containers for infectious waste or containers intended for disinfection.

\section{2b. Preparation of soldiers}

It is vital to mention the role of the army in ensuring civil protection. Protection against biological contamination is perceived as a process of ensuring the safety of people, armaments, specialized equipment, and facilities in contaminated conditions (cf. Gilchrist \& Collier, 2020). It is based on the use of air purification systems, protective properties of the area and its infrastructure, and continuous control of the threat level.

Protection against biological contamination consists of:

- personal protection against contamination

- collective protection against contamination.

Protection tasks include:

- organizing projects related to minimizing (further) spread of the biological agent

- providing soldiers with personal and collective protection against contamination and preventive measures ensuring their ability to work in contaminated conditions

- preparing soldiers to use personal and collective means of protection against contamination and to use skillfully the protective properties of combat equipment, the area, and its infrastructure

- ensuring technical efficiency of collective protection systems for fighting vehicles, command posts, repair and service facilities, and medical facilities (Michailiuk, 2015a, p. 220). 
The armed forces specify the concept of "personal protection against contamination" (ISOPS), which defines personal measures designed to protect individuals against various types of infection that can attack the organism. Personal protection measures are defined as items used "in defense against chemical, biological, radiological, and nuclear weapons, personal equipment intended for personal physical protection against the effects of the use of chemical, biological and radioactive substances" (AAP-6, 2017, p. 242).

Physical protection measures include:

- respiratory protection (gas masks)

- skin protection (protective clothing).

The gas mask should be functional and provide respiratory and facial protection against biological agents. Standard respiratory protection devices include filtering gas masks (Harmata, 2014, pp. 32-47) MP-5 and MP-6 (see photo 5).

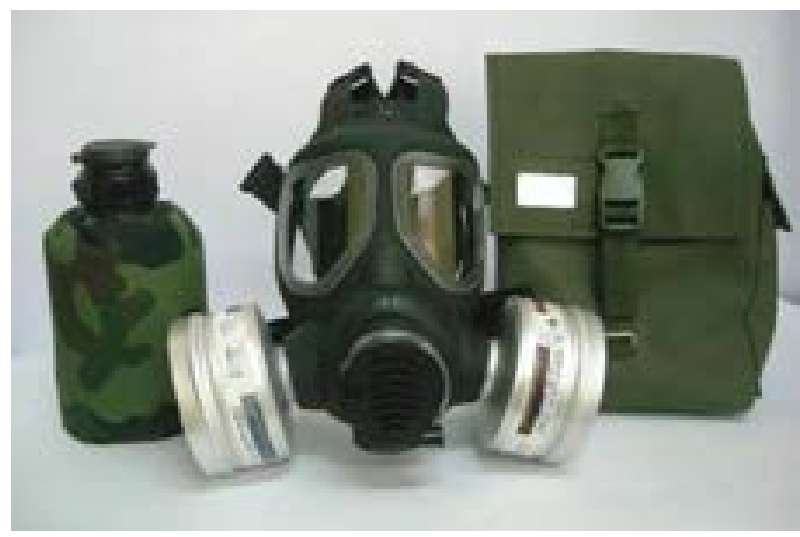

Photo 5. MP-6 mask (set)

Source: Władysław Harmata’s private archive.

Given the mechanism of providing protection, protective clothing of the Polish Armed Forces is divided into two groups (Harmata, 2014, pp. 111-146):

- isolating - military protective clothing made of materials constituting a barrier against biological, poisonous, radioactive agents, and protecting soldiers against harmful effects (general-military clothing, overlays, special clothing)

- filtration (permeable) - military protective clothing made of filtration materials that protect skin against contamination, for example, general military (combat) clothing and special clothing (overalls and underwear). 
- In this case, the main requirement is to protect one's body and the parts of the head left unprotected by a gas mask against biological agents. For skin protection, there is OP-1, L-1 or L-2 insulated protective clothing, or FOO-1 protective filter clothing (see Photo 6).

Photo 6. Protective filter clothing FOO-1

Source: Władysław Harmata’s private archive.

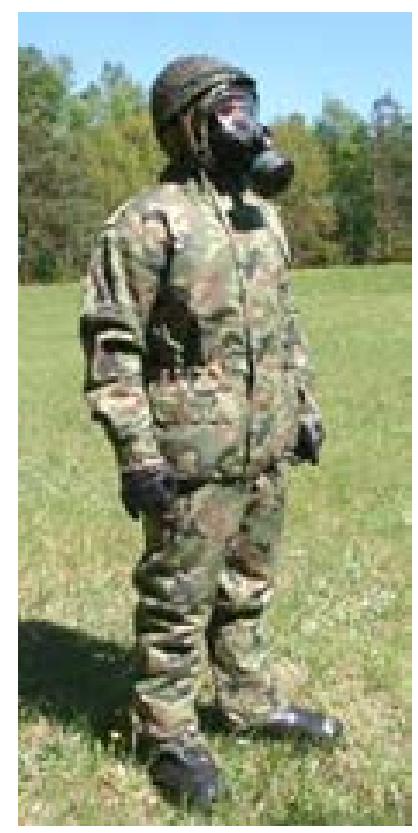

Władysław Harmata presented technical requirements for personal protective equipment and materials used to make it in a specific, condensed and very accurate form, listing:

- protective properties - long protection time and service life, which involves preserving protective properties, mechanical strength, ignition resistance, water resistance, resistance to petroleum products, masking properties, non-toxicity of materials in contact with skin, sweat resistance;

- comfort of use - the smallest load on one's body (ensuring field of vision, ease of breathing, low difficulty of use and low heat load, ease of putting on and taking off, compatibility with other equipment items, uniform for combat)

- logistics parameters - low weight and low volume when packed, possibility of long storage and multiple use, susceptibility to decontamination (Harmata, 2014, p. 31).

It is worth emphasizing that assigning properties to one of these groups does not mean that it is not desirable in others.

The equipment of soldiers related to personal protective measures for reducing risk of infection is handled by persons from the logistics division of a military unit. Each soldier, after arriving at the parent military unit, receives a gas mask and protective clothing as part of their personal equipment. The subunit 
commanders have to teach soldiers to use personal means of protection against infection by conducting training sessions devoted to the use of gas masks and protective clothing, including the performance of full-time tasks. Exercise alone is not enough; it is also necessary to learn to care continuously for the proper state of personal protective measures.

To ensure high level of effectiveness of special means of protection against infection, it is necessary to provide continuous care, that is daily (by users) and periodic inspections (by appropriate functionaries from the sub-department and department).

Filter absorbers for the military (the gas mask should also be equipped with spare filter absorbers, which are compliant with the regulations in force), protective clothing, gloves and footwear are made from materials that protect against biological agents. These filter-absorbers are designed to protect the respiratory tract against particles larger than approx. 1-1.5 microns. Personal filter protective uniforms (mainly used against dangerous chemicals) are also intended to protect against biological agents (Michailiuk, 2015a, p. 221). Protective clothing should be supplied in an amount that will ensure that the wearer can operate under dangerous conditions for 24 hours (NATO, 2014).

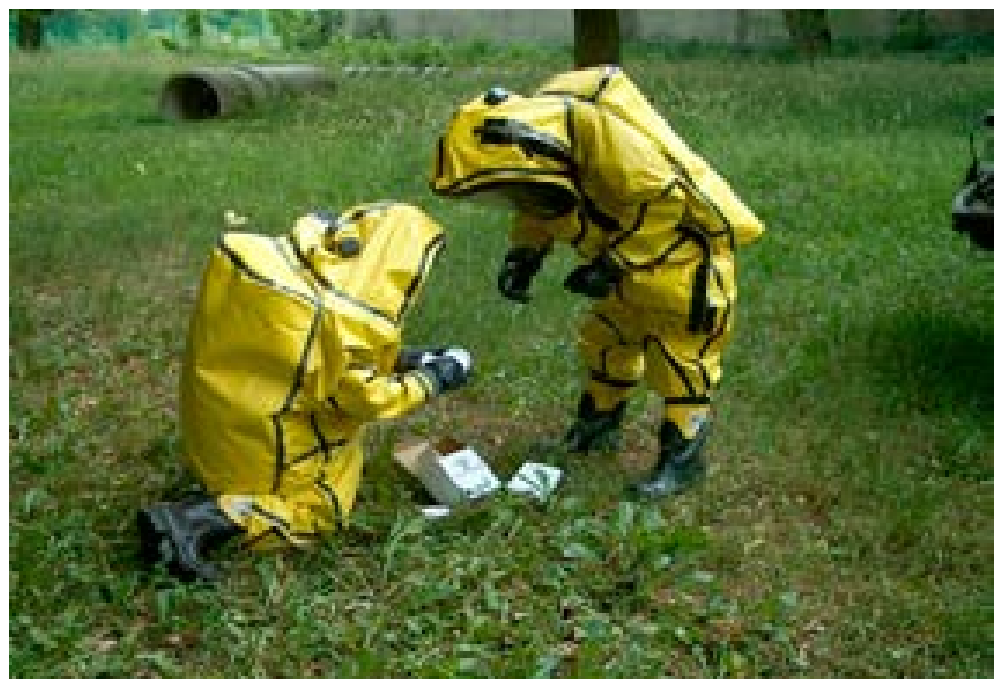

Photo 6. Collection of biological samples and preparation for transport Source: Krzysztof Przeworski’s private archive. 


\section{Summary and conclusions}

As rightly observed by Susan Scott and Christopher Duncan, we have a much deeper knowledge about diseases in the 20th century since many effective vaccines and drugs are produced, there are experts specializing in epidemiology and molecular biology, numerous series of diagnostic tests are conducted, and we can use technology that allows us to determine genome sequence of a new virus within a few days of its appearance (Scott \& Duncan, 2020, p. 9). Nevertheless, each new plague poses a significant threat, which can have an adverse impact on our existence and destroy the order in a modern region (epidemic) and even the world (pandemic). Władysław Harmata warns that vaccines can prevent some diseases; however, when the pathogenic agent is unknown, this method of protection becomes worthless. Antibiotics are effective against particular types of bacteria or certain classes of microorganisms, but not against all of them (Harmata, 2013, p. 32). The current situation when a new virus is spreading rapidly is dangerous not only to our health, but also to our lives. While the world awaits the development of an adequate vaccine, we must comply with relevant rules on isolation from the harmful biological agent by using personal protection measures.

It would be reasonable to create a guide on behavior in the case of this threat. The guide must be accessible to the average recipient, clearly indicating the desired rules of conduct (what to do, what to avoid).

It is crucial to bear in mind that, regardless of whether health service is civil, military, state or private, there is no opportunity to provide assistance to everyone at the same time in a limited area in the case of unusual and massive losses. Infectious diseases require not only the support of human potential, but also resources in the form of places in hospitals. It is possible that dedicated hospital wards will not have enough places. In addition to overcrowded medical facilities, employees of the Emergency Room and admission rooms will also be overworked, which can hinder assistance to regular patients and suspension of non-lifesaving procedures. Furthermore, the spectrum of infection, public panic and confinement in homes will threaten the resources of blood banks and blood products. "Among all other negative outcomes, [it] would also lead to reduced medical support" (Bergquist \& Rinaldi, 2020).

People should be particularly careful when faced with the threat of an epidemic. It is obligatory to follow recommendations from the authorities and take care of personal safety by limiting contact with others and securing personal 
protection measures. In the case of a pandemic, following good practices seems to be beneficial. Since the threat seems to be imminent, it is worth analyzing the situation in countries that have been affected by an infectious disease and have already implemented some solutions that bring or - in the near future - are going to bring positive effects. Patience is also an important element of survival - while coronavirus is changing our everyday life (Goodwin-Hawkins \& Keech, 2020), but humanity has already experienced epidemics and pandemics in its history. Each time it was possible to return to normality.

\section{REFERENCES}

Bergquist, R., \& Rinaldi, L. (2020). Covid-19: Pandemonium in our time. Geospatial Health, 15(1). DOI: https://doi.org/10.4081/gh.2020.880

Bradshaw, R. A., \& Stahl, P. D. (2020). On pandemics, pandemonium, and possibilities... FASEB BioAdvances 1-2(2020). DOI: https://dx.doi.org/10.1096/fba.2020-00023

Carlos, R. C. (2020). Pandemic [Editorial]. Journal of the American College of Radiology, 17(6), 691-692. DOI: https://doi.org/10.1016/j.jacr.2020.04.017

Coronavirus: European Standard for medical supplies made freely available to facilitate increase of production. (2020). Retrieved from https://ec.europa.eu/commission/ presscorner/detail/en/ip_20_502

Dezynfekcja, sterylizacja, antyseptyka. (n.d.). Retrieved from https://www.lekarski. umed.wroc.pl/sites/default/files/mikrobiologia/files/Dezynfekcja_i_sterylizacja.pdf

Draft assumptions for the Act on civil protection of 29 December 2017. (2017). Retrieved from https://www.ock.gov.pl/prawo/projekty_aktow_prawnych

Flemming, M., Gołębiewski, J., \& Olbryś S. (1997). Ochrona ludności - wybrane zagadnienia. Warszawa: Firex.

Gilchrist, E. S., \& Collier, P. J. (2020). Biocides and decontamination agents including sporicides for decontamination in hospitals. In J. Walker (Ed.), Decontaminations in Hospitals and Healthcare (Second Edition) (pp. 241-258). Sawston, Cambridge: Woodhead Publishing.

Goodwin-Hawkins, B., \& Keech, D. (2020). On epidemiological ruination. Social Anthropology, 28(2). DOI: 10.1111/1469-8676.12794

Harmata, W. (2013). Ochrona przed skażeniami cz. I - Wspótczesne zagrożenia. Podstawy teoretyczne indywidualnej ochrony przed skażeniami. Warszawa: Wojskowa Akademia Techniczna.

Harmata, W. (2014). Ochrona przed skażeniami cz. II - Rozwiazania praktyczne indywidualnych środków ochrony przed skażeniami. Warszawa: Wojskowa Akademia Techniczna.

Kańtoch, M. (n.d.). Człowiek a wirusy. Retrieved from alergia.org.pl/pacjent/inne/człowiek.htm 
Krawczyk, E. (2020). Koronawirus. Wszystko, co musisz wiedzieć, żeby się zabezpieczyć. Bielsko-Biała: Pascal.

Lemke, M., Apostolopoulos, Y., \& Sönmez, S. (2020). Syndemic frameworks to understand the effects of COVID-19 on commercial driver stress, health, and safety. Journal of Transport and Health, 18. DOI: https://doi.org/10.1016/j.jth.2020.100877

Michailiuk, B. (2014). Ochrona ludności i ratownictwo. In D. Majchrzak (Ed.), Zarzadzanie kryzysowe w wymiarze lokalnym. Organizacja, procedury, organy i instytucje (pp. 243-259). Warszawa: Akademia Obrony Narodowej.

Michailiuk, B. (2015a). Broń biologiczna jako zagrożenie bezpieczeństwa państwa. Warszawa: Akademia Obrony Narodowej.

Michailiuk, B. (2015b). Funkcjonowanie budowli ochronnych w aspekcie ochrony ludności. In: M. Kopczewski, A. Kurkiewicz, S. Mikołajczak (Eds.), Paradygmaty badań nad bezpieczeństwem. Jednostki, grupy i społeczeństwa, vol. 2 (pp. 591-606). Poznań: Wyższa Szkoła Bezpieczeństwa.

Michailiuk, B. (2017). Ochrona ludności: wybrane problemy. Warszawa: Wyższa Szkoła Wojenna.

Moore, P. (2009). Tajemnicze choroby współczesnego świata. Nowe zagrożenia, wirusy, bakterie, zarazki. Warszawa: Bellona.

NATO. (2014). Stanag 2352 (Ed. 8), Nuclear, Biological and Chemical (NBC) Defence Equipment - Operational Guidelines.

NATO. (2017). AAP-6. Słownik terminów i definicji NATO zawierający wojskowe terminy $i$ ich definicje stosowane w NATO. Accessible at wcnjik.wp.mil.pl

Pyrć, K. (2015). Ludzkie koronawirusy. Postępy Nauk Medycznych, XXVIII(4B), 48-54.

Regulation of the Council of Ministers of 21 September 2004 on constant defensive vigilance (Dziennik Ustaw 2004, No. 219, item 2218).

Quammen, D. (2014). Ebola: the Natural and Human History. London: The Bodley Head.

Scott, S., \& Duncan, C. (2020). Czarna śmierć. Epidemie w Europie od starożytności do czasów współczesnych. Warszawa: Bellona.

Sholapurkar, S. L. (2020). Facemasks: The Evidence and Myths amongst experts and public officials regarding wearing of protective Face-masks during the covid-19 pandemic. BMJ. Retrieved from https://www.researchgate.net/publication/340808648_ Facemasks_The_Evidence_and_Myths_amongst_experts_and_public_officials_regarding_wearing_of_protective_Face-masks_during_the_covid-19_pandemic

Sobolewski, G., Majchrzak, D., \& Tocicka, J. (2016). Obrona cywilna i ochrona ludności $w$ zintegrowanym systemie kierowania systemem obronnym państwa $i$ zarządzania kryzysowego [research work]. Warszawa: Akademia Obrony Narodowej.

Surgical masks. Requirements and test methods (UNE-EN 14683:2019+AC). (n.d.). Retrieved from https://www.ivami.com/en/biocidal-activities-and-toxicology-with-disinfectants25-accredited-tests/6335-en-14683-medical-face-masks-requirement-and-tests-methods-une-en-14683-2019-ac 
Ustawa z dnia 5 grudnia 2008 r. o zapobieganiu oraz zwalczaniu zakażeń i chorób zakaźnych u ludzi [Act of 5 December 2008 on preventing and combating infections and infectious diseases among people] (Dziennik Ustaw 2020, item 284, 322, 374).

WHO. (2020a). Novel Coronavirus (2019-nCoV) Situation Report 22.. Retrieved from https://www.who.int/docs/default-source/coronaviruse/situation-reports/20200211sitrep-22-ncov.pdf?sfvrsn=fb6d49b1_2

WHO. (2020b). Novel Coronavirus (2019-nCoV). Situation Report 50. Retrieved from https://www.who.int/docs/default-source/coronaviruse/situation-reports/20200310sitrep-50-covid-19.pdf?sfvrsn=55e904fb_2

WHO. (2020c). Novel Coronavirus (2019-nCoV). Situation Report 51. Retrieved from https://www.who.int/docs/default-source/coronaviruse/situation-reports/20200311sitrep-51-covid-19.pdf?sfvrsn=1ba62e57_10

WHO Director-General. (2020, Mar 11). Opening remarks at the media briefing on COVID-19. Retrieved from https://www.who.int/dg/speeches/detail/who-directorgeneral-s-opening-remarks-at-the-media-briefing-on-covid-19---11-march-2020

Żółtowski, Z. (1969). Broń i wojna biologiczna w świetle zachodniej doktryny wojny totalnej. Warszawa: Ministerstwo Obrony Narodowej. 